\title{
PENGARUH IMPLEMENTASI SISTEM ERP TERHADAP PENINGKATAN INDEKS KEPUASAN NASABAH DI PT. BANK X DI MEDAN, INDONESIA
}

\author{
NOVI NATALIA PADANG \\ Fakultas Ekonomi Program Studi Akuntansi Universitas Katolik Santo Thomas \\ novipadang06@gmail.com
}

\begin{abstract}
ABSTRAK
Makalah ini bertujuan untuk mengkaji berbagai konsep terkait pengembangan definisi dan dimensi manajemen hubungan nasabah, serta mencoba mengembangkan model manajemen hubungan nasabah yang komprehensif, khususnya di PT. Bank X. Permasalahan yang akan diangkat dalam makalah ini adalah bagaimana mengembangkan konsep, definisi dan dimensi manajemen hubungan nasabah dan kedua, bagaimana mengembangkan model enterprise resource planning yang dapat diterapkan pada PT. Bank X. Pendekatan yang digunakan dalam menulis makalah ini adalah pendekatan kualitatif, yaitu metode penelitian yang digunakan untuk memeriksa objek ilmiah. Implikasi akademis dalam makalah ini adalah bahwa ada pemahaman teoritis tentang penyebab keberhasilan dan kegagalan perusahaan dalam menerapkan Aplikasi Sistem Enterprise Resource Planning (ERP) .Sementara itu, implikasi praktis untuk jurnal ini diharapkan dapat menjadi pertimbangan bagi para pelaku usaha, khususnya di industri jasa perbankan dalam mengimplementasikan Sistem ERP. Fokus konseptual yang dikembangkan dalam makalah ini adalah untuk meneliti dimensi manajemen hubungan nasabah sehingga model yang menggambarkan manajemen hubungan nasabah di sektor perbankan dapat dikembangkan. Kontribusi asli untuk penulisan jurnal ini dapat memberikan perspektif baru pada ERP yang lebih proaktif.
\end{abstract}

Kata kunci: Enterprise Resouce Planning, Peningkatan Indeks Kepuasan Pelanggan. Klasifikasi JEL: G21.

\section{PENDAHULUAN}

PT. Bank. X adalah bank pertama yang didirikan dan dimiliki oleh pemerintah Indonesia. Kemampuan PT. Bank. X untuk beradaptasi dengan perubahan dan kemajuan lingkungan, sosial budaya dan teknologi tercermin melalui peningkatan identitas perusahaan yang berkelanjutan dari waktu ke waktu. Pelayanan yang baik dan sesuai dengan keinginan pelanggan tentu akan memberikan kepuasan bagi pelanggannya. Sebagai perusahaan besar, PT. Bank X menggunakan Enterprise Resource Planning (ERP) adalah sistem yang berfungsi untuk mengoptimalkan sumber daya yang ada di perusahaan dalam mencapai tujuan. Menjalankan ERP di perusahaan memerlukan perangkat lunak pendukung, termasuk SAP, Oracle, Microsoft, Solar Soft, Infor, Sage dan lainnya. Bentuk ERP di masing-masing perusahaan akan berbeda sesuai dengan kebutuhan dan ruang lingkup perusahaan. Perusahaan dapat membuat ERP mereka sendiri, melibatkan pengembang atau membeli yang telah disediakan oleh beberapa perusahaan. Dalam SAP terdiri dari beberapa modul antara Finance and Control (FICO), Production Planning (PP), Material Management (MM), Human Resources (HR), Customer Relationship Management (CRM), Quality Management (QM), dan Project System (PS). 


\section{TELAAH TEORI DAN PENGEMBANGAN HIPOTESIS}

\section{Perencanaan Sumber Daya Perusahaan}

ERP adalah sistem terintegrasi yang digunakan dalam organisasi untuk pemrosesan data. Sistem tersebut menghubungkan manajemen bisnis dan proses produksi. Sistem ERP mengotomatiskan dan mengintegrasikan proses bisnis yang dapat ditemukan di lingkungan produksi, mengintegrasikan organisasi untuk memperoleh informasi yang berkaitan dengan rantai pasokan, pelanggan, sumber daya manusia, keuangan, dan sebagainya. Enterprise Resource Planning (ERP) menurut James A. Hall (2011) adalah model sistem informasi yang memungkinkan organisasi untuk mengotomatiskan dan mengintegrasikan proses bisnis utamanya. Enterprise Resource Planning menurut Turban, Rainer, dan Potter (2007) dirancang dan dirancang untuk memecahkan masalah di 8 area fungsional sistem informasi dengan mengintegrasikan area fungsional melalui database. Enterprise Resource Planning (ERP) menurut O'Brien, J. A., \& Marakas, G. M. (2010) adalah sistem perusahaan yang mencakup semua fungsi dalam perusahaan yang digerakkan oleh beberapa modul perangkat lunak terintegrasi untuk mendukung proses bisnis internal perusahaan. Menurut Anindita (2018) setiap sistem ERP memiliki modul yang berbeda, namun biasanya terdapat beberapa modul dasar yang dimiliki sistem ERP yang canggih. Fungsi modul dasar ini dianggap penting untuk berbagai jenis perusahaan. Penggunaan ERP dalam suatu perusahaan membutuhkan software pendukung antara lain SAP, Oracle, Microsoft, Solar Soft, Infor, Sage, Plex, Abas dan lain-lain. Sistem SAP atau SAP (soltius.co.id) adalah software berbasis ERP atau Enterprise Resources Planning yang digunakan untuk melakukan pengelolaan aktivitas sehari-hari suatu organisasi atau perusahaan. Tujuannya agar SAP membuat semua kegiatan pengelolaan, pemantauan, dan pemrosesan informasi jauh lebih efektif dan efisien daripada sebelumnya. Menurut blog.opencloud.id, modul-modul yang ada di SAP memiliki fungsi masing-masing dan bisa digunakan untuk keberlangsungan perusahaan. Dari beberapa modul yang ditawarkan, terdapat beberapa modul yang paling sering digunakan oleh perusahaan seperti di bawah ini:

1. Modul Keuangan dan Kontrol (FICO) terdiri dari kombinasi beberapa hal, mulai dari standar akuntansi untuk uang dan manajemen kas, konsolidasi yang diperlukan untuk penyusunan laporan keuangan, hukum umum dan akuntansi biaya, misalnya akuntansi pusat biaya dan analisis laba;

2. Modul Perencanaan Produksi (PP) dapat membantu kegiatan bisnis Anda dalam menjalankan proses perencanaan serta mengendalikan kegiatan bisnis di dalam perusahaan. Tidak hanya itu, modul PP juga memiliki data utama dan berbagai solusi yang mungkin Anda butuhkan dalam melakukan produksi;

3. Modul Material Management (MM) sangat berguna untuk kegiatan bisnis dalam melakukan pembelian (procurement) dan manajemen inventaris. Modul ini berfungsi untuk merekam semua aktivitas ini setiap hari. Pada saat yang sama, modul MM juga terintegrasi penuh dengan beberapa modul lain, seperti FICO, PP, dan lainnya;

4. Modul Penjualan dan Distribusi (SD) akan berperan dalam kegiatan bisnis Anda dengan fungsinya yang mampu meningkatkan efisiensi aktivitas yang terjadi di dalam perusahaan dalam hal memproses pesanan pembeli, misalnya penjualan, pengiriman, dan penagihan. Modul SD juga terintegrasi penuh dengan modul lain, misalnya FICO, PP, MM, dan lainnya;

5. Modul Sumber Daya Manusia (SDM) berguna dalam memastikan integrasi semua proses yang terjadi di dalam departemen dengan nama yang sama, yaitu departemen SDM. Proses 
ini meliputi administrasi pegawai, aplikasi/pendaftaran, pembiayaan untuk perjalanan kerja, gaji rapat, dan lain-lain;

6. Modul Customer Relationship Management (CRM) terkait langsung dengan back-end sistem ERP, sistem kecerdasan bisnis, sistem manajemen rantai pasokan dan lain-lain, fungsi dalam memberikan informasi penting dari analisis kepuasan pelanggan sehingga perusahaan sebagai pebisnis dapat memahami kliennya dengan lebih baik;

7. Modul Quality Management (QM) berperan bagi perusahaan untuk memeriksa kualitas kegiatan yang terjadi dalam serangkaian proses logistik;

8. Modul Sistem Proyek (PS) dapat membantu perusahaan untuk menciptakan integrasi antara semua proses yang terjadi dalam perencanaan, eksekusi, dan kontrol proyek yang sedang berlangsung.

\section{Manajemen Hubungan Pelanggan}

Andika (2019) mengatakan Customer Relationship Management (CRM) merupakan salah satu bentuk strategi yang diterapkan oleh perusahaan untuk mempertahankan pelanggan lama dan berupaya untuk meningkatkan loyalitas pelanggan serta mendapatkan pelanggan baru bagi perusahaan. Secara teknologi, CRM merupakan sistem yang memuat informasi atau data pelanggan yang terintegrasi dengan proses bisnis perusahaan untuk memudahkan manajemen dalam menganalisis kepuasan pelanggan terhadap produk, layanan pelanggan, dan layanan purna jual yang diberikan perusahaan kepada pelanggannya. Menurut Newell (2011) yang dikutip dalam co.id Pelajaran Customer Relationship Management merupakan modifikasi dan pembelajaran perilaku konsumen setiap saat dari setiap interaksi, perlakuan terhadap pelanggan dan membangun kekuatan antara konsumen dan perusahaan.

Menurut Frow \& Payne (2009) yang mendefinisikan manajemen hubungan pelanggan sebagai pendekatan strategis fungsional dengan menciptakan nilai pemegang saham melalui pengembangan hubungan yang sesuai dengan pelanggan dan segmen pelanggan. Johnson \& Weistern (2004) dalam Stoor et.al (2010) mengatakan bahwa manajemen hubungan pelanggan merupakan strategi bisnis yang melibatkan pemilihan dan pengelolaan hubungan pelanggan untuk mengoptimalkan nilai perusahaan dalam jangka panjang. Kebutuhan pemasaran relasional muncul sebagai akibat dari globalisasi industri. CRM sangat kompleks terkait dengan departemen marketing, sales, service, finance, dan logistic, dalam penerapannya membutuhkan keterlibatan manajemen puncak. Kebutuhan pemasaran relasional muncul sebagai akibat dari globalisasi industri. Fokus bergeser dari promosi produk ke menciptakan nilai terkondisi setiap saat. Ini dipupuk melalui pergerakan nilai, inovasi dalam teknologi, dan pergeseran kekuasaan dari produsen ke konsumen.

Menurut Don Taspcott terdapat empat dimensi CRM yaitu planning, untuk memastikan keberhasilan bisnis yang menggunakan CRM mengetahui dengan tepat apa yang ingin dicapai dengan strategi CRM. Kedua, yang berkaitan dengan manusia, yaitu semua pihak yang berkepentingan, yaitu karyawan dan mitra, harus terkoordinasi secara interfungsional dengan upaya CRM. Ketiga proses (proses) tentang bagaimana pelanggan menghubungi perusahaan harus didefinisikan secara jelas, yang terakhir adalah platform yaitu penentuan tujuan, koordinasi target dengan pihak terkait, memastikan proses, Software IT harus dipilih yang merespon kebutuhan CRM untuk bisnis.Menurut Wong, Hu \& Yu (2010) yang mendefinisikan manajemen hubungan pelanggan, yaitu cara untuk meningkatkan kepuasan pelanggan melalui analisis media tahun 2016 kepada pelanggan, merinci informasi untuk meningkatkan kemampuan bersaing perusahaan. Ada dua dimensi dalam penelitian yang dilakukan pada bank-bank di China yaitu 
customer center dan customer satisfaction. Manajemen Hubungan Pelanggan (CRM) tidak hanya tentang penerapan teknologi, tetapi merupakan strategi untuk mempelajari lebih lanjut tentang kebutuhan dan perilaku pelanggan untuk mengembangkan hubungan yang lebih kuat dengan mereka. Menurut Sarjana Ekonomi. co.id fungsi, manfaat dan dimensi hubungan CRM.

Fungsi Dari Manajemen Hubungan Pelanggan adalah:

1. Identifikasi faktor-faktor yang sangat penting bagi pelanggan;

2. Menjunjung tinggi filosofi yang berorientasi pada pelanggan (customer centric) ;

3. Mengadopsi pengukuran berdasarkan sudut pandang pelanggan;

4. Menetapkan proses layanan pelanggan end-to-end;

5. Memberikan dukungan pelanggan yang sempurna;

6. Menangani keluhan atau keluhan nasabah;

7. Catat dan ikuti semua aspek penjualan;

8. Buat informasi holistik tentang informasi layanan dan penjualan dari pelanggan.

Manfaat Customer Relationship Management adalah:

1. Mendorong Loyalitas Pelanggan. Aplikasi CRM ini memungkinkan perusahaan untuk memanfaatkan informasi dari semua titik kontak dengan pelanggan, baik melalui web, pusat panggilan, atau melalui pemasaran dan staf layanan lapangan. Konsistensi dan aksesibilitas informasi ini memungkinkan penjualan dan layanan yang lebih baik dengan berbagai informasi penting tentang pelanggan ini;

2. Mengurangi Biaya. Dengan kemampuan perusahaan dalam penjualan dan layanan, ada biaya yang dapat dikurangi. Misalnya dengan memanfaatkan teknologi web. Aplikasi CRM ini juga memungkinkan penjualan atau layanan dengan biaya yang jauh lebih rendah dalam skema program pemasaran tertentu dan terfokus. Pergi ke pelanggan yang tepat pada waktu yang tepat;

3. Meningkatkan Efisiensi Operasional. Otomatisasi penjualan dan proses layanan dapat mengurangi risiko memburuknya kualitas layanan. Penggunaan teknologi web dan call center, misalnya, akan dapat mengurangi hambatan birokrasi dan biaya serta proses administrasi yang mungkin timbul;

4. Peningkatan Waktu ke Pasar. Aplikasi CRM ini juga memungkinkan kami untuk membawa produk ke pasar lebih cepat dengan informasi pelanggan yang lebih baik. Dengan kemampuan untuk menjual melalui web, waktu, geografis, dan ketersediaan sumber data dapat dikesampingkan untuk mempercepat penjualan produk-produk ini;

5. Peningkatan pendapatan. Aplikasi CRM ini memberikan berbagai informasi untuk meningkatkan pendapatan dan laba perusahaan. Dengan aplikasi CRM ini, kami dapat melakukan penjualan dan layanan melalui website sehingga peluang penjualan global tanpa perlu memberikan upaya khusus untuk mendukung penjualan dan layanan.

Dimensi Hubungan dalam CRM adalah:

1. Reliance (Trust) adalah keyakinan bahwa seseorang akan menemukan apa yang dia inginkan pada orang lain, dan bukan apa yang dia takutkan. Kepercayaan ini melibatkan perasaan aman dan percaya diri pada pasangan;

2. Keandalan (Keandalan) adalah kemampuan untuk memberikan layanan secara akurat seperti yang dijanjikan;

3. Responsif adalah kemampuan karyawan untuk membantu konsumen memberikan pelayanan dengan cepat sesuai dengan apa yang diinginkan konsumen; 
4. Komunikasi Dua Arah adalah hubungan yang baik yang merupakan komunikasi dua arah, memberikan tanggapan terhadap apa yang dialami.

Manfaat perusahaan menerapkan CRM (Putu:2015)

1. Meningkatkan proses komunikasi dua arah dengan nasabah, sehingga proses transaksi menjadi lebih cepat dan akurat;

2. Memperoleh informasi yang diperlukan untuk memberikan pelayanan yang memuaskan kepada pelanggan;

3. Mempercepat pengambilan keputusan manajemen;

4. Meningkatkan pertumbuhan bisnis;

5. Dengan menggunakan alat analitik, dapat meningkatkan pemahaman organisasi pelanggan;

6. Meningkatkan produktivitas penjualan dengan memetakan proses menggunakan teknologi baru.

Ab Hamid dan McGrath (2005) ada 12 dimensi e-CRM, seperti:

1. Kualitas Informasi

2. Kemudahan Navigasi

3. Layanan Pelanggan Berkualitas

4. Pemenuhan

5. Mengintegrasikan Saluran Pemasaran

6. Komunitas Online

7. Penghargaan

8. Tingkat Personalisasi

9. Keamanan Situs

10. Layanan bernilai tambah

11. Perceived trust

12. Harga Menarik

\section{METODE PENELITIAN}

Metode Penelitian dalam melakukan penelitian ini penulis memilih metode penelitian kualitatif. Sebagaimana disampaikan oleh Sugiyono (2009) metode penelitian kualitatif adalah metode penelitian yang digunakan untuk memeriksa objek ilmiah. Dalam penelitian kualitatif, pengumpulan data tidak dipandu oleh teori, tetapi dipandu oleh fakta yang ditemukan selama penelitian di lapangan. Teknik pengumpulan data yang digunakan dalam penelitian ini meliputi wawancara, observasi dan dokumentasi. Penulis akan mencoba mengumpulkan data tentang Sistem ERP dan kemudian menjelaskannya. Objek penelitian dilakukan di PT Bank X di Medan dengan fokus pada ERP.

\section{HASIL PENELITIAN}

Penggunaan ERP untuk nasabah bisa mendapatkan informasi tingkat suku bunga tentang produk PT . Bank X melalui penyelidikan atau kutipan harga Pemasaran kegiatan seperti pelacakan kontak pelanggan, termasuk panggilan penjualan, kunjungan, dan surat nasabah dapat mempertahankan data tentang nasabah.

\section{KESIMPULAN}

Penggunaan ERP sangat penting dalam perusahaan perbankan untuk meningkatkan keuntungan perusahaan. sistem ERP dapat meminimalkan kesalahan entri data dan memberikan informasi yang akurat secara real time untuk semua pengguna sistem ERP dapat melacak semua 
transaksi (seperti faktur, daftar pengepakan, nomor RMA, dan pembayaran) yang terlibat dalam urutan penjualanKarena pelanggan selalu menginginkan kemudahan dan dimanjakan. Perkembangan teknologi perbankan selalu dilakukan untuk memenuhi kebutuhan masyarakat luas.

\section{DAFTAR PUSTAKA}

Ab Hamid, N. \& McGrath, G. 2005. The Diffusion of internet activity on retail web sites : A

Customer relationship model. Communication of the IIMA, 5(2): 35-46.

Frow, Pennie, and Adrian Payne. (2009). "Customer Relationship Management : A Strategic

Perspective." volume 3: 7-27. Journal of business market management. https://doi.10.1007/s12087-008-0035-8.

Hall, James. (2011). Sistem Informasi Akuntansi, Edisi Empat, Salemba Empat, Jakarta.

Imasari, Kartika dan Kezia Kurniawati Nursalin. (2011). Pengaruh Customer Relationship

Management Terhadap Loyalitas Pelanggan pada PT. BCA Tbk. Jurnal Ekonomi,

Volume 10 Nomor 3, 168-234.

O’Brien dan Marakas. (2010). Management System Information. McGraw Hill, New York.

Octa, Andhika. (2019).Literature Review : Meningkatkan Kepuasan Pelanggan Di Bengkel Resmi Menggunakan Sistem Manajemen Pelanggan Elektronik, 4221.

Pratama, Agus Eka Pratama, and I Putu. (2014). Smart City Beserta Cloud Computing dan Teknologi- Teknologi Pendukung Lainnya. Bandung : Informatika.

Program, Dosen, and Studi Administrasi. “Customer Relationship Management” 2, no. 1 (2016): 83-98.

Rainer., K,Turban, E. \& Potter, R.E. (2007). Introduction to Information Systems: Supporting and Transforming Business, John Wiley and Sons, NewJersey.

Storr Tramaine, Forbes Delgardo, Carraher Shawn M. \& Biard Thomas.(2009). Customer

Relationship Management

in RBC Royal Bank of Canada (Bahamas) : An Analysis of The Present and a Pathway to Future

Success, Proceeding of The Academy of Marketing Studies. Vol 14, P. 45-48.

Sugiyono. (2009). Metode penelitian kuantitatif, Kualitatif dan R\&D. Bandung : Alfabeta.

Wang Fan, Hu Fang \& Yu Li, 2010. The Application of Customer Relationship Management in Invesment Banks Asian Social Science. Vol 16, No. 10. 6(10). https://doi:10.5539/ass.v6n10p178.

Anindita. (2018, September 2). Apa Itu ERP software dan apa Kegunaannya bagi Bisnis Anda?.Businesstech. https://www.hashmicro.com/id/blog/apa-itu-erp-software/

Downey. (2001, June 27). Tapscott makes the case for CRM. Itbusinessca. https://www.itbusiness.ca/news/tapscott-

makes-the-case-for-crm/6109 Ekonomi. (2020, April 5). Customer Relationship Management. sarjanaekonomi.co.id.https://sarjanaekonomi.co.id/customer-relationshipmanagement.

Kedang, Serenata. (2019, June 11). Modul SAP yang Paling Sering Digunakan Perusahaan. https://blog.opencloud.id/sap/modul-sap-yang-umum-digunakan.

Sterling. (2020, Mei 8). SAP Indonesia, Jenis Modul Dan Tujuan Implementasi SAP Business One.https://www.sterling-team.com/news/sap-indonesia-jenis-modul-dantujuanimplementasi-sap-business-one. 